\title{
The rs74794265 SNP of the SREKI Gene is Associated with COPD in Kashi, China
}

\author{
Zulipikaer Abudureheman ${ }^{1} *$ \\ $\mathrm{Li} \mathrm{Li}{ }^{2} *$ \\ XueMei Zhong ${ }^{2} *$ \\ JingRan $X u^{2}$ \\ Hui Gong' \\ Subinuer Yilamujiang' \\ Jie $\operatorname{Ren}^{2}$ \\ ChengXin $\mathrm{Xie}^{2}$ \\ AiFang Zheng ${ }^{2}$ \\ Dilala Tuerxun ${ }^{2}$ \\ Ayiguzali Abudukadeer ${ }^{2}$ \\ Paierda Aini ${ }^{2}$ \\ AiMin $X u^{3}$ \\ XiaoGuang Zou ${ }^{2}$ \\ 'Department of Clinical Research Center \\ of Infectious Diseases (Pulmonary \\ Tuberculosis), First People's Hospital of \\ Kashi, Kashi, People's Republic of China; \\ ${ }^{2}$ Department of Respiratory and Critical \\ Care Medicine, First People's Hospital of \\ Kashi, Kashi, People's Republic of China; \\ ${ }^{3}$ Department of Clinical Laboratory, First \\ People's Hospital of Kashi, Kashi, People's \\ Republic of China \\ *These authors contributed equally to \\ this work
}

Correspondence: AiMin Xu; XiaoGuang

Zou

Email 519202069@qq.com;

ZXGKSII@yeah.net
Background: Kashi city is situated near the Taklamakan desert and has a high incidence rate of chronic obstructive pulmonary disease (COPD). In this study, we aimed to explore the relationship between the SNP of the SREK1 gene locus rs74794265 and the susceptibility to COPD among the Uyghur population in Kashi, XinJiang, China.

Methods: A total of 541 patients with COPD and 534 control subjects were included in this study. Sanger sequencing was used to analyze the SNP of the SREK1 gene locus rs74794265 site. The distribution of genotypes in different genetic models between the case and control group were analyzed by logistic regression analysis after adjusting for age, sex, and smoking history.

Results: The $S R E K 1$ gene SNP locus rs 74794265 included two genotypes, namely, C/C and C/ $\mathrm{T}$, of which $\mathrm{C} / \mathrm{C}$ was the wildtype; The risk of COPD was significantly lower in patients with heterozygous $\mathrm{C} / \mathrm{T}$ in $\mathrm{rs} 74794265[p=0.0236, \mathrm{OR}=0.3677$ (0.1547-0.8742)], and the allele frequency of $\mathrm{T}$ was also significantly lower in the patient group $[p=0.0245, \mathrm{OR}=0.3728(0.1577-$ 0.8811)]. The heterozygous $\mathrm{C} / \mathrm{T}$ of rs 74794265 among non-smoking COPD patients was significantly lower than other COPD patients $[p=0.0298, \mathrm{OR}=0.3217(0.1156-0.8949)]$, and there was no significant correlation of the heterozygous $\mathrm{C} / \mathrm{T}$ genotype in smokers.

Conclusion: We found that the rs74794265 heterozygous $\mathrm{C} / \mathrm{T}$ genotype significantly reduces the risk of COPD. The $\mathrm{C} / \mathrm{T}$ genotype is likely a protective factor for COPD in the Kashi region. We speculate that the occurrence of COPD in this area is probably more related to desert climate condition and genetic factors than smoking status.

Keywords: COPD, SREK1 gene polymorphism, rs74794265 locus, Uyghur population

\section{Introduction}

Chronic obstructive pulmonary disease (COPD) is a chronic respiratory disorder that progresses slowly and is characterized by an obstructive ventilatory pattern, which is rarely reversible. The main risk factors are active smoking, genetic factors, and air pollution. In particular, COPD has been a major public health problem and will remain a challenge for clinicians in the 21 st century. In recent years, COPD has been the focus of pulmonary research given its high prevalence and increased morbidity and mortality rates, which pose formidable challenges for health-care systems. The projection for 2020 indicates that COPD will be the third leading cause of death worldwide, which is responsible for early mortality, high death rates, and significant cost to health systems. ${ }^{1,2}$

Kashi city is located to the west of XinJiang province, China, and is close to Taklamakan desert which is the second largest desert in the world. The desert climate and geographic location of Kashi area are favorable for the development of 
COPD, because people living in this area are frequently exposed to dust storms. In these conditions, the prevalence rates of COPD increase yearly, and the Uyghur population appear most affected with COPD in the Kashi area. Furthermore, we found that the increased incidence of COPD in this area is also related to genetic factors and customs of the local people. In this study, we investigated the unique polymorphic site in the exonic region of the SREK1 gene and discuss the relationship between the SREK1 gene SNP in the rs 74794265 locus and the susceptibility to COPD among the Uyghur population in Kashi, XinJiang, China.

SREK1 is a member of the SR protein superfamily with an additional glutamic acid-lysine (EK)-rich domain that regulates RNA processing by modulating multiple SR proteins. The SR proteins play significant roles in constitutive and alternative splicing of pre-mRNAs as well as in nuclear export, nonsense-mediated decay, and translation of mRNAs. ${ }^{3}$ SREK1 is a direct interactor and regulator of SRSF6 and is particularly interesting because one of its target mRNAs is the TATA-box binding protein associated factor 1 (TAF1). ${ }^{4}$ A previous study showed that SRSF6 regulates alternative splicing of genes involved in DNA damage response and DNA repair in HeLa cells. ${ }^{5}$ However, thus far, no study has shown the correlation between SREK1 and COPD. Sanger sequencing showed that only one SNP of the SREK1 gene was founded and SREK1 gene polymorphism confers protection against COPD. The role of rs74794265 in the regulation of SREK1 expression levels and the mechanisms via which it influences COPD require further investigation.

\section{Materials and Methods}

A total of 1075 subjects were included in this study: 541 patients with COPD in the case group and 534 healthy people in the control group. COPD patients were diagnosed based on the results from multiple examinations including the ratio of forced expiratory volume in 1 second/forced vital capacity (FEV1/FVC ratio, 70\%) and FEV1 ( $80 \%$ predicted), according to the Global Initiative for Chronic Obstructive Lung Disease criteria. ${ }^{6}$ All patients and controls were matched for age, sex, and BMI; all subjects underwent pulmonary function testing and showed normal spirometry results. The exclusion criteria for the control group were: 1) other respiratory diseases such as asthma, tuberculosis, fibrosis, or lung cancer; 2) suffering from any respiratory symptoms or non-respiratory diseases such as diabetes or cardiovascular disease; 3) unable to perform the pulmonary function tests.
All subjects were required to complete a questionnaire about basic information and provide $5 \mathrm{~mL}$ peripheral blood for testing. Written informed consent was obtained from all participating subjects. The project was approved by the Ethics Committee of the First People's Hospital of Kashi. This study was conducted in accordance with the tenets of the Declaration of Helsinki.

Data analyses were performed using SPSS software (version 18.0, IBM Corporation, Armonk, NY, USA). Quantitative data are presented as mean \pm standard deviation or medians (interquartile ranges). Independent $t$-test was used to compare the difference between age and BMI, because this data showed approximately normal distribution which was supported by the QQ plots. Annual household income, FEV1\%, and FEV1/FVC not conforming to normal or approximately normal distribution were compared using Mann-Whitney $U$-test. Differences in sex, smoking status, smoking index, coal combustion (Burning coal for cooking and heating), and charcoal combustion (Burning charcoal for cooking and heating) were assessed by chi-square test $\left(\chi^{2}\right)$. The SNP genotypic distribution in all subjects was evaluated by Hardy-Weinberg equilibrium (HWE), using the Fisher's exact test. Unconditional logistic regression analysis was performed to identify independent risk factors of COPD in each SNP genetic model. Odds ratio (OR), 95\% confidence intervals (CI), and stratified analysis were presented by multivariable logistic regression analysis before or after adjusting for age, sex, and BMI. For all analyses, $\mathrm{P}<0.05$ was considered to indicate statistical significance. The relationship between the COPD risk and the tag-SNPs under different genotypic models was designed for analysis by SNP Stats. ${ }^{7}$

\section{Results}

\section{Characteristics of Study Population}

The characteristics of all objects including average age, BMI, smoking, and pulmonary function (FEV, FVC) were significantly different between the patient and control groups shown in Table 1.

\section{Analysis of the SREKI Gene Polymorphism}

The multiple logistic regression model was adjusted for age, sex, and smoking history in all subjects, and the HWE analysis was applied. Results of the HWE analysis are shown in Table 2. After adjusting for age, sex, and BMI 
Table I Characteristics of the Study Population

\begin{tabular}{|c|c|c|c|}
\hline Variable & Case $n=541(\%)$ & Control n=534 (\%) & $\mathbf{P}$ \\
\hline Age (years) (mean \pm SD) & $61.11 \pm 12.26$ & $54.86 \pm 10.73$ & $<0.001$ \\
\hline Sex, n (\%) & & & 0.009 \\
\hline Male & $280(51.75)$ & $234(43.82)$ & \\
\hline Female & $261(48.24)$ & $300(56.18)$ & \\
\hline BMI $\left(\mathrm{kg} / \mathrm{m}^{2}\right),($ mean \pm SD $)$ & $23.56 \pm 4.22$ & $25.55 \pm 4.17$ & $<0.001$ \\
\hline Annual household income (CNY, yuan) (mean \pm SD) & $16,939(10,294-23,442)$ & I5,298 (9762-23,057) & 0.197 \\
\hline Smoking status, $\mathbf{n}(\%)$ & & & $<0.001$ \\
\hline Yes & $124(22.92)$ & $69(12.92)$ & \\
\hline No & $417(77.07)$ & $465(87.08)$ & \\
\hline Smoking index ${ }^{a}, \mathrm{n}(\%)$ & & & $<0.001$ \\
\hline$\leq 1$ & $417(77.07)$ & $465(87.08)$ & \\
\hline $\mathrm{I} \leq \mathrm{SI} \leq 400$ & $98(18.11)$ & $52(9.74)$ & \\
\hline $400<\mathrm{SI} \leq 800$ & $16(2.97)$ & II (2.06) & \\
\hline $\mathrm{SI}>800$ & $10(1.85)$ & $6(1.12)$ & \\
\hline \multicolumn{4}{|l|}{ Coal combustion, $n$ (\%) } \\
\hline Yes & $513(94.82)$ & $516(96.63)$ & 0.144 \\
\hline No & $28(5.18)$ & $18(3.37)$ & \\
\hline \multicolumn{4}{|l|}{ Charcoal combustion, $\mathbf{n}(\%)$} \\
\hline Yes & $519(95.93)$ & $500(93.63)$ & 0.09 \\
\hline No & $22(4.07)$ & $34(6.37)$ & \\
\hline \multicolumn{4}{|l|}{ Lung function (mean \pm SD) } \\
\hline $\mathrm{FEV}, \%$ & $69.00(53.92-82.00)$ & $86.00(74.00-98.00)$ & $<0.001$ \\
\hline $\mathrm{FEV}_{1} / \mathrm{FVC}$ & $0.602(0.55-0.66)$ & $0.80(0.75-0.86)$ & $<0.001$ \\
\hline
\end{tabular}

Note: ${ }^{\text {a }} \mathrm{SI}=$ number $\times$ year.

Abbreviation: BMJ, Body Mass Index.

among COPD patients, all data were analyzed using unconditional logistic regression analysis. Table 3 shows the results of the logistic regression model wherein the SNP of the rs 74794265 locus SREK1 gene included two genotypes of $\mathrm{C} / \mathrm{C}$ and $\mathrm{C} / \mathrm{T}$ respectively; In the Additive and Dominant genetic model, the risk of COPD was significantly lower in the case group with heterozygous $\mathrm{C} / \mathrm{T}$ in rs74794265 $[\mathrm{p}=0.0236, \mathrm{OR}=0.3677(0.1547-0.8742)]$, and the gene frequency of $\mathrm{T}$ was also significantly lower in the allele model in the case group $[\mathrm{p}=0.0245, \mathrm{OR}=0.3728$

Table 2 HWE Analysis

\begin{tabular}{|l|c|c|c|c|c|}
\hline & Type & HOMA & HET & HOMR & \multirow{2}{*}{ HWE } \\
\cline { 2 - 5 } & Genotype & T/T & C/T & C/C & \\
\hline rs747944265 & All & 0 & 28 & $104 \mathrm{I}$ & $\mathrm{I}$ \\
(SREKI) & Case & 0 & 8 & 527 & $\mathrm{I}$ \\
& Control & 0 & 20 & $5 \mathrm{I} 4$ & $\mathrm{I}$ \\
\hline
\end{tabular}

Abbreviation: HWE, Hardy-Weinberg's equilibrium test.
(0.1577-0.8811)]. We speculate that the heterozygous $\mathrm{C} / \mathrm{T}$ genotype can confer further protection against COPD.

Smoking is considered the main risk factor of COPD in reports; ${ }^{8,9}$ therefore, we explored the SREK1 gene SNP in the rs74794265 locus in smokers to explore the correlation the rs74794265 SNP with smoking. We evaluated the covariates related with smoking, including annual household income, coal combustion and charcoal combustion (Table 1). There were no significant differences between the cases and controls. Interestingly, there was only one SNP frequency in the smokers with heterozygous $\mathrm{C} / \mathrm{T}$ in rs74794265 (Table 4). There was no significant difference in smoking status between the case and control groups in any genetic model. Table 5 showed that among the no smokers, there were significant differences with heterozygous $\mathrm{C} / \mathrm{T}$ in $\mathrm{rs} 74794265$ in all genetic models between the cases and controls, and the frequency of the $\mathrm{T}$ allele was also significantly 
Table 3 Analysis of Genotypes of Rs74794265

\begin{tabular}{|c|c|c|c|c|c|c|}
\hline SNP & Model & Genotype & Case & Control & OR (95\% Cl) & P value \\
\hline \multirow{9}{*}{$\begin{array}{l}\text { rs74794265 } \\
(\text { SREKI) }\end{array}$} & \multirow[t]{3}{*}{ Additive } & $T / T$ & 0 & 0 & \multirow[t]{3}{*}{$0.3677(0.1547-0.8742)$} & \multirow[t]{3}{*}{$0.02355^{*}$} \\
\hline & & $\mathrm{C} / \mathrm{T}$ & 8 & 20 & & \\
\hline & & $\mathrm{C} / \mathrm{C}$ & 527 & 514 & & \\
\hline & \multirow[t]{2}{*}{ Dominant } & $\mathrm{T} / \mathrm{T}, \mathrm{C} / \mathrm{T}$ & 8 & 20 & \multirow[t]{2}{*}{$0.3677(0.1547-0.8742)$} & \multirow[t]{2}{*}{$0.02355^{*}$} \\
\hline & & $\mathrm{C} / \mathrm{C}$ & 527 & 514 & & \\
\hline & \multirow[t]{2}{*}{ Recessive } & $T / T$ & 0 & 0 & \multirow[t]{2}{*}{ NA (NA-NA) } & \multirow[t]{2}{*}{ NA } \\
\hline & & $\mathrm{C} / \mathrm{C}, \mathrm{C} / \mathrm{T}$ & 535 & 534 & & \\
\hline & \multirow[t]{2}{*}{ Allele } & $\mathrm{T}$ & 8 & 20 & \multirow[t]{2}{*}{$0.3728(0.1577-0.88 \mathrm{II})$} & \multirow[t]{2}{*}{$0.02455^{*}$} \\
\hline & & C & 1062 & 1048 & & \\
\hline
\end{tabular}

Notes: Logistic regression: corrected sex, age, and BMI; $* P<0.05$.

Abbreviations: OR, Odds ratio; $95 \% \mathrm{Cl}, 95 \%$ confidence interval.

Table 4 SNP of Rs74794265 Among Smokers

\begin{tabular}{|c|c|c|c|c|c|c|}
\hline SNP & Model & Genotype & Case & Control & OR $(95 \% \mathrm{Cl})$ & $P$ value \\
\hline \multirow[t]{6}{*}{ rs74794265 (SREKI) } & Additive & $\mathrm{T} / \mathrm{T}$ & 0 & 0 & $0.6244(0.0304-12.83)$ & 0.76 \\
\hline & & $\mathrm{C} / \mathrm{T}$ & I & I & & \\
\hline & & $\mathrm{C} / \mathrm{C}$ & 122 & 68 & & \\
\hline & Dominant & $\begin{array}{c}\mathrm{T} / \mathrm{T}, \mathrm{C} / \mathrm{T} \\
\mathrm{C} / \mathrm{C}\end{array}$ & $\begin{array}{c}1 \\
122\end{array}$ & $\begin{array}{c}1 \\
68\end{array}$ & $0.6244(0.0304-12.83)$ & 0.76 \\
\hline & Recessive & $\begin{array}{c}\mathrm{T} / \mathrm{T} \\
\mathrm{C} / \mathrm{C}, \mathrm{C} / \mathrm{T}\end{array}$ & $\begin{array}{c}0 \\
123\end{array}$ & $\begin{array}{c}0 \\
69\end{array}$ & NA & NA \\
\hline & Allele & $\begin{array}{l}\mathrm{T} \\
\mathrm{C}\end{array}$ & $\begin{array}{c}1 \\
245\end{array}$ & $\begin{array}{c}1 \\
137\end{array}$ & $0.6279(0.03 \mathrm{II}-12.68)$ & 0.7615 \\
\hline
\end{tabular}

Abbreviations: OR, Odds ratio; $95 \% \mathrm{Cl}, 95 \%$ confidence interval.

Table 5 SNP of Rs74794265 in No Smokers

\begin{tabular}{|c|c|c|c|c|c|c|}
\hline SNP & Model & Genotype & Case & Control & OR (95\% Cl) & P-value \\
\hline \multirow[t]{9}{*}{ rs74794265 (SREKI) } & \multirow[t]{3}{*}{ Additive } & $T / T$ & 0 & 0 & \multirow[t]{3}{*}{$0.3217(0.1156-0.8949)$} & \multirow[t]{3}{*}{$0.0298 I^{*}$} \\
\hline & & $\mathrm{C} / \mathrm{T}$ & 5 & 19 & & \\
\hline & & $\mathrm{C} / \mathrm{C}$ & 367 & 446 & & \\
\hline & \multirow[t]{2}{*}{ Dominant } & $\mathrm{T} / \mathrm{T}, \mathrm{C} / \mathrm{T}$ & 5 & 19 & \multirow[t]{2}{*}{$0.3217(0.1156-0.8949)$} & \multirow[t]{2}{*}{$0.0298 I^{*}$} \\
\hline & & $\mathrm{C} / \mathrm{C}$ & 367 & 446 & & \\
\hline & \multirow[t]{2}{*}{ Recessive } & $\mathrm{T} / \mathrm{T}$ & 0 & 0 & \multirow[t]{2}{*}{ NA } & \multirow[t]{2}{*}{ NA } \\
\hline & & $\mathrm{C} / \mathrm{C}, \mathrm{C} / \mathrm{T}$ & 372 & 465 & & \\
\hline & \multirow[t]{2}{*}{ Allele } & $\mathrm{T}$ & 5 & 19 & \multirow[t]{2}{*}{$0.3267(0.1181-0.9036)$} & \multirow[t]{2}{*}{$0.03115^{*}$} \\
\hline & & C & 739 & 911 & & \\
\hline
\end{tabular}

Note: $* p<0.05$.

Abbreviations: OR, Odds ratio; $95 \% \mathrm{Cl}, 95 \%$ confidence interval.

lower in the Allele model in the case group than the Discussion

control group. This indicates that the SNP of COPD is a lung disease characterized by incomplete reverrs74794265 has no correlation with smoking status. sible airflow limitation, which progressively develops and 
is associated with lung damage particles and gas abnormalities of the inflammatory response. Studies ${ }^{10}$ have indicated the existence of familial clustering of COPD. A twin study showed that a higher risk of COPD was found in identical twins than in fraternal twins, and $60 \%$ of individual risks were determined by genetic factors. ${ }^{11}$ Therefore, investigation of genetic factors may be beneficial for the early prevention and diagnosis of COPD.

In our current study, we investigated 1075 subjects belonging to the Uyghur population from the Kashi region and found that the unique polymorphic site of the SREKI gene with heterozygous $\mathrm{C} / \mathrm{T}$ in rs 74794265 was apparently associated with reducing COPD risk in this population who have lived here for a long term. Moreover, reports point out that tobacco smoke exposure is the primary risk factor of COPD and 10-15\% of smokers finally develop COPD. ${ }^{8,9}$ Therefore, we compared the SNP of rs 74794265 among non-smoking COPD patients and found that there was no correlation between rs74794265 and smoking status. This indicated that the occurrence of COPD in this area is most likely related to poor air condition and genetic factors than smoking because of the special geographical location of Kashi.

Several GWAS have reported that multiple SNPs in the CXCL10, ${ }^{12}$ ADRB $2,{ }^{13}$ HHIP,${ }^{14}$ and SERPIN ${ }^{15}$ genes contribute to COPD susceptibility. However, association of the SNPs in the SREK1 gene with COPD is still poorly understood. Our findings first revealed the rs74794265 locus on SREK1 is obviously related to COPD susceptibility. As the major risk factor for COPD, the associations of cigarette smoking with SNPs variants were evaluated. Stratified analysis showed that the rs 74794265 SNP was no significant difference in smoking status between the case and control groups in any genetic model. In addition, silicosis, which is a chronic progressive fibrotic lung inflammation, may increase the risk of COPD. Research indicates that the functional variant of the CPM gene ${ }^{16}$ and the rs2609255 polymorphism in the FAM13A gene ${ }^{17}$ are associated with silicosis susceptibility in a Chinese population. In our study, we discussed the susceptibility of SREK1 rs74794265 C>T polymorphism in COPD. However, whether the rs 74794265 SNP was directly associated with COPD or through silicosis increase the risk of COPD, remains unclear.

Our study has some limitations. The number of subjects was relatively small and the effects of second-hand smoke or other smoke-inhalation methods in non-smoking individuals were not considered. In summary, to our knowledge, this is the first account of the beneficial association of the rs74794265 SNP in the SREK1 gene with COPD and in Uyghur population residing in the Kashi region.

\section{Ethics Statement}

The project was approved by the Ethics Committee of First People's Hospital of Kashi. This study was conducted in accordance with the tenets of the Declaration of Helsinki.

\section{Acknowledgments}

Zulipikaer Abudureheman, Li Li, and XueMei Zhong contributed equally to this work as primary authors (co-first authors). Aimin $\mathrm{Xu}$ and Xiaoguang Zou are cocorresponding authors.

\section{Funding}

Tianshan Youth Project of Xinjiang Uyghur Autonomous Region (2019Q143).

\section{Disclosure}

I would like to declare on behalf of my co-authors that our paper was submitted solely to this journal and the work described is original research that has not been published previously, and not under consideration for publication elsewhere, in whole or in part.

\section{References}

1. López-Campos JL, Wan T, Soriano JB. Global burden of COPD. Respirology. 2016;21(1):14-23.

2. Raherison C, Girodet PO. Epidemiology of COPD. Eur Respir Rev. 2009;18(114):213-221.

3. Li J, Barnard DC, Patton JG. A unique glutamic acid-lysine (EK) domain acts as a splicing inhibitor. J Biol Chem. 2002;277 (42):39485-39492.

4. Hernández IH, Cabrera JR, Santos-Galindo M, et al. Pathogenic SREK1 decrease in Huntington's disease lowers TAF1 mimicking X-linked dystonia parkinsonism. Brain. 2020;143(7):2207-2219.

5. Xiao Y, Peng Z, Shuqiang F, et al. SRSF6 regulates alternative splicing of genes involved in DNA damage response and DNA repair in HeLa cells. Oncol Rep. 2020;44(5):1851-1862.

6. Vogelmeier CF, Criner GJ, Martinez FJ, et al. Global strategy for the diagnosis, management, and prevention of chronic obstructive lung disease 2017 report: GOLD executive summary. Eur Respir J. 2017;49(3):1700214

7. Solé X, Guinó E, Valls J, et al. SNPS tats: a web tool for the analysis of association studies. Bioinformatics. 2006;22(15):1928-1929.

8. Rabe KF, Watz H. Chronic obstructive pulmonary disease. Lancet. 2017;389(10082):1931-1940.

9. Lareau SC, Fahy B, Meek P, et al. Chronic Obstructive Pulmonary Disease (COPD). Am J Respir Crit Care Med. 2019;199(1):P1-P2.

10. McCloskey SC, Patel BD, Hinchliffe SJ, et al. Siblings of patients with severe chronic obstructive pulmonary disease have a significant risk of airflow obstruction. Am J Respir Crit Care Med. 2001;164(8 Pt 1):1419-1424. 
11. Ingebrigtsen $\mathrm{T}$, Thomsen SF, Vestbo $\mathrm{J}$, et al. Genetic influences on chronic obstructive pulmonary disease-a twin study. Respir Med. 2010;104(12):1890-1895.

12. Yan W, Qipeng Z, Lian D, et al. The effects of CXCL10 polymorphisms on COPD susceptibility. Mol Genet Genomics. 2018;293 (3):649-655

13. Li JX, Fu WP, Zhang J, et al. A functional SNP upstream of the ADRB2 gene is associated with COPD. Int J Chron Obstruct Pulmon Dis. 2018;13:917-925.

14. Ortega-Martínez A, Pérez-Rubio G, Ambrocio-Ortiz E, et al. The SNP rs13147758 in the HHIP gene is associated with COPD susceptibility, serum, and sputum protein levels in smokers. Front Genet. 2020;11:882.
15. Li L, Li S, Zhong X, et al. SERPINE2 rs16865421 polymorphism is associated with a lower risk of chronic obstructive pulmonary disease in the Uygur population: a case-control study. J Gene Med. 2019;21 (9):e3106.

16. Chu M, Wu S, Wang W, et al. Functional variant of the carboxypeptidase M (CPM) gene may affect silica-related pneumoconiosis susceptibility by its expression: a multistage case-control study. Occup Environ Med. 2019;76(3):169-174.

17. Wang W, Yu Y, Wu S, et al. The rs2609255 polymorphism in the FAM13A gene is reproducibly associated with silicosis susceptibility in a Chinese population. Gene. 2018;661:196-201.

\section{Publish your work in this journal}

The International Journal of COPD is an international, peer-reviewed journal of therapeutics and pharmacology focusing on concise rapid reporting of clinical studies and reviews in COPD. Special focus is given to the pathophysiological processes underlying the disease, intervention programs, patient focused education, and self management protocols. This journal is indexed on PubMed Central, MedLine and CAS. The manuscript management system is completely online and includes a very quick and fair peer-review system, which is all easy to use. Visit http://www.dovepress.com/testimonials.php to read real quotes from published authors. 